\title{
Kompetencijų modelio kūrimas ir taikymo perspektyvos Lietuvos valstybès tarnyboje
}

\author{
Reda Rekašienė \\ Valstybès tarnybos departamentas \\ Labdariug. 8. Vilnius \\ Tadas Sudnickas \\ Mykolo Romerio universitetas \\ Valakupiug. 5, LT-10101 Vilnius \\ doi:10.13165/VPA-14-13-4-04
}

Anotacija. Straipsnyje apžvelgiama Valstybès tarnybos departamento veikla rengiant kompetenciju modeli Lietuvos valstybès tarnyboje. Atsižvelgiant $i$ valstybès strateginiuose dokumentuose išdèstytas nuostatas buvo inicijuotas projektas parengti kompetenciju modeli. Straipsnyje pristatomi kompetenciju modelio rengimo veiksniai ir aplinkybès, taip pat argumentuotos modelio kūrimo prielaidos. Pateikiamos kompetenciju modelio taikymo galimybès ịvairiose valstybès tarnybos žmogiškuju ištekliu vadybos srityse, leidžiančios palaipsniui pereiti nuo tradicinès prie kompetencijomis grịstos žmogiškuju ištekliu vadybos.

Raktažodžiai: kompetencija, kompetenciju modeliai, kompetencijomis grịtas valdymas, valstybès tarnyba, viešasis sektorius.

Keywords: competency, competency model, competency-based management, civil service, public sector.

\section{Ivadas}

Viena iš pastaruoju metu tyrëjų plačiausiai nagrinėjamų žmogiškųjų išteklių vadybos temų - darbuotojų kompetencijų valdymas. Davidas C. McCllellandas [7] paskatino šios krypties tyrinejjimus, pastebėdamas, kad asmens veiklos ir karjeros 
sẻkmė nebūtinai priklauso nuo gautų išsilavinimą liudijančių diplomų, formalių, tradiciškai vertinamų akademinių žinių lygio ar formalių kvalifikacijos įvertinimo diplomų. [2]. Richardas Boyatzis kompetenciją apibūdina kaip „esminę individo charakteristiką, priežasties ir pasekmès ryšiais susijusią su puikia veikla“. Gerai žinomos ir žmogiškųjų išteklių vadybos praktikų pamègtos knygos „Competence at Work“ autorès Signe M. Spencer ir Lyle M. Spencer [9, p. 9] taip apibrezžia kompetencijas: „kompetencijos - tai esminès individo savybès, kurios priežasties ir pasekmès ryšiais susietos su efektyvia (puikia) kriterijais apibrèžta veikla darbe arba kokioje nors situacijoje.“

Esminès individo charakteristikos (kompetencijos) suprantamos kaip ilgalaikès asmens savybès, kurios leidžia nuspèti jo elgseną ateityje.

Kriterijais apibrèžta veikla reiškia tai, kad kompetencijos nuspejja gerą ar prastą veiklą, tokią veiklą, kuri gali būti matuojama naudojantis specifiniais kriterijais arba standartais.

Skiriami penki kompetencijų tipai: motyvai, individualios savybės ir bruožai, asmeninès nuostatos bei savęs suvokimas, žinios ir ịgūdžiai.

Kompetencijomis remiasi jų modeliai, kurių kūrimas, vertinimas ir diegimas yra vienas iš svarbiausių vadybos, viešojo administravimo ir verslo psichologijos nagrinėjamų klausimų. Kompetencijų modeli galima apibrèžti kaip konkrečios pareigybès ar artimų pagal prigimtị pareigybių grupei būdingų išmatuojamų igūdžių, žinių, patirties, elgsenos ir asmeninių savybių rinkinius, reikalingus puikiai veiklai. Privačios organizacijos pirmosios susidomèjo kompetencijų modeliais ir pradejjo ieškoti naujų, pažangių metodų, kad galètų padidinti savo veiklos efektyvumą ir taip tapti konkurencingesnès globaliame pasaulyje. Plintant naujosios viešosios vadybos požiūriui, skatinančiam geriausios verslo praktikos perkèlimą ị viešaji sektorių, šios idejjos populiarèjo ir tarp viešojo sektoriaus organizacijų ir institucijų. Kompetencijų modelių diegimo tendenciją puikiai iliustruoja viešojo sektoriaus organizacijų JAV, Didžiojoje Britanijoje, Australijoje, Kanadoje ir Naujojoje Zelandijoje pasiekimai šioje srityje [1], [5], [6].

Lietuva žengia svarbius žingsnius taikant kompetencijų modelius valstybės tarnyboje. Šiuo metu Valstybės tarnybos departamentas yra ta institucija, kuri dalyvauja rengiant kompetencijų modelị Lietuvos valstybės tarnybai, o ateityje galètų koordinuoti kompetencijomis grindžiamą žmogiškųjų išteklių vadybos diegimą visoje Lietuvos valstybès tarnyboje.

Veiksmingos valstybès tarnybos sukūrimas ir jos modernizavimas buvo ir išlieka prioritetiniu mūsų valstybès uždaviniu. Apie kompetencijomis grịstą žmoniškųjų išteklių valdymo modelį valstybès tarnyboje kalbama tiek Vyriausybės 20122016 metų programos igyvendinimo prioritetinèse priemonèse, tiek 2008-2012 m. Vyriausybės veiklos programoje. Šią kryptị taip pat nurodo ir Viešojo valdymo tobulinimo 2012-2020 m. programa, 2014-2020 metų Nacionalinė pažangos programa bei Lietuva 2030.

Visos organizacijos veiklos efektyvumo, neišskiriant ir žmogiškųjų išteklių vadybos, užtikrinimas yra vienas svarbiausių kiekvienos organizacijos strategijos 
aspektų. Šiame kontekste kiekvieno darbuotojo reikiamų kompetencijų, o kartu ir veiklos efektyvumo užtikrinimas yra ambicingas ir ilgalaikis uždavinys.

\section{Kompetencijų modelio Lietuvos valstybès tarnybai kūrimas}

Šiuo metu nèra vienos reikalavimų sistemos, t. y. net analogiškoms pareigybẻms gali būti nustatyti skirtingi išsilavinimo ir patirties reikalavimai. Taip pat nėra nustatyta, kokias žinias, igūdžius gebejimus turi turèti vienas ar kitas pareigas užimantis valstybės tarnautojas. Taigi, trūksta vienodos reikalavimų valstybės tarnautojų žinioms, ịgūdžiams ir gebejjimams sistemos, kuria remiantis būtų užtikrinta skaidresné pretendentų i valstybès tarnautojo pareigas atranka bei objektyvesnis valstybès tarnautojų tarnybinès veiklos vertinimas, taip pat būtų tiksliau identifikuojami mokymo poreikiai, nuosekliau rengiami mokymo planai.

Atsižvelgiant ị tai ir ị strateginiuose dokumentuose numatytus tikslus bei uždavinius Valstybės tarnybos departamentas 2009 m. pradejjo vykdyti 2007-2013 m. Žmogiškųjų išteklių plètros veiksmų programos 4 prioriteto „Administraciniu gebejjimų stiprinimas ir viešojo administravimo efektyvumo didinimas" igyvendinimo priemonès VP1-4.1-VRM-01-V „Valstybès tarnybos sistemos stiprinimas“ projektą „Valstybės tarnyboje būtinų kompetencijų analizè ir valstybės tarnautojų pareigybių aprašymų katalogas“.

Igyvendinant Projektą buvo sukurtas Valstybės tarnautojų kompetencijų modelis ir jo taikymo metodika (toliau - Metodika). Juos sukūrè UAB Žmogaus studijų centras kartu su UAB „Ernst \& Young Baltic“ 2014 m. Metodikos pagrindu buvo parengtas ir išleistas leidinys „Valstybės tarnautojų kompetencijų modelis ir jo taikymo metodika“.

Šiame leidinyje išdèstytas Lietuvos valstybès tarnybai sukurtas kompetenciju modelis bei pateikiami kompetencijų nustatymo kriterijai. Siūloma, kad kompetencijų modelị sudarytų trys kompetencijų grupès: bendrosios kompetencijos (reikalingos bet kurioje veiklos srityje), vadybinès ir lyderystès (reikalingos vadovaujant istaigos ar padalinio veiklai) bei specifinès ir profesinès kompetencijos (reikalingos vykdant profesinès veiklos funkcijas). Toks kompetencijų grupių pasirinkimas yra pagrindžiamas kriterijais. Pažymima ir įvertinama kompetencijų sąsajos su valstybès tarnybos misija, valstybès tarnybos ir valstybès tarnautojų veiklos etikos principais, valstybès tarnautojo pareigomis, įstaigos tikslais ir uždaviniais svarba. Kita vertus, svarbus yra ir specifiškumas - nustatant Lietuvos valstybės tarnautojų kompetencijas buvo vadovautasi ir tokiais kriterijais kaip kompetencijų sąsajos su veikla, veiklos specifika ir sritis, pareigybès hierarchija. Neabejotinai svarbu ir tai, kad kompetencijų grupių pasirinkimas būtų pagrịstas moksliniais kompetencijų tyrimais, būtų funkcionalus ir patogus vartotojui.

Vadovaujantis mokslinès literatūros analize ị kompetencijų modelị įtrauktos tos kompetencijos, kurios, tyrimų rezultatais, daro teigiamą ịtaką veiklos efektyvumui. Mokslininkai (McClelland, 1973, 1998; Spencer, Spencer, 1993; Boyatzis, 
Goleman, Luthans, ir kt. (remiantis Boyatzis, 2008), Cherniss, Goleman, 2001) nustate kompetencijas, kurios skiria sėkmingus ir vidutinius darbuotojus ịvairiose veiklos srityse ir turinčius skirtingą hierarchinį statusą:

- kognityvinès kompetencijos: analitinis mąstymas, konceptualus mąstymas ir pan. ${ }^{1}$;

- emocinès (asmeninio efektyvumo) kompetencijos: savęs pažinimas, emocijų pažinimas ir valdymas, pasitikèjimas, patikimumas, lankstumas ir pan.;

- socialinès kompetencijos: socialinis supratingumas ir santykių valdymas, bendradarbiavimas, bendravimas, įtaka ir pan.

- pasiekimų kompetencijos²: orientacija ị pasiekimus (rezultatus, tikslą), optimizmas, iniciatyvumas ir kt. [13].

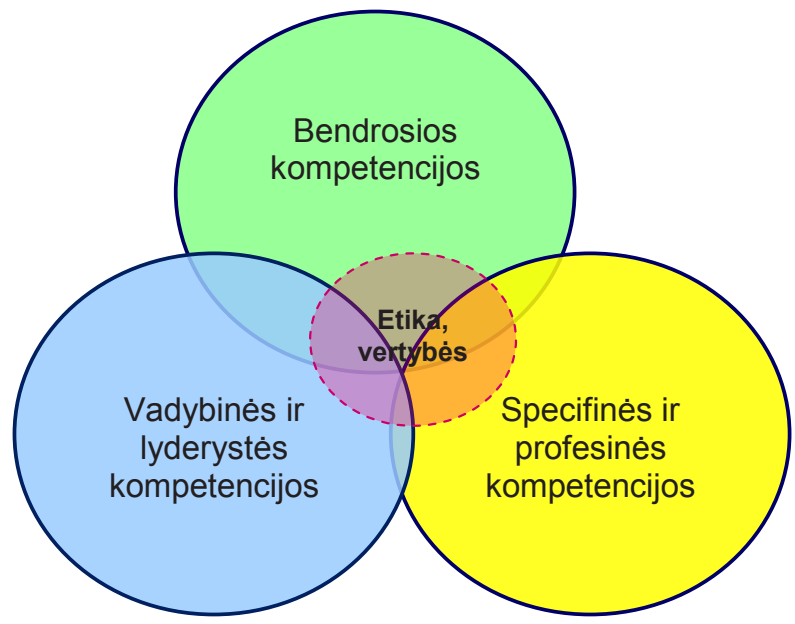

1 pav. Lietuvos valstybės tarnautojų kompetencijų modelị sudarančios

kompetencijų grupės (šaltinis: „Valstybės tarnautojų kompetencijų modelis ir jo taikymo metodika“" 2014, 5 pav., 23 p.)

1 Kadangi kognityvinių kompetencijų sudètinè dalis ir pagrindas yra bendrieji gebejjimai, kurie vertinami centralizuotoje valstybès tarnautojų atrankoje, tokios kompetencijos kaip ,analitinis mąstymas“, „konceptualus mąstymas“ į siūlomų kompetencijų sąrašą yra neįtrauktos, vadovaujantis kompetencijų nustatymo kriterijumi „,kompetencijų lakoniškumas, specifiškumas“, tačiau įtraukta kompetencija ,analizè ir pagrindimas“, kuri apibréžia analitinius gebėjimus elgesị apibūdinančiais indikatoriais.

2 Pasiekimų kompetencija kai kurių autorių nėra išskiriama kaip atskira, ji priskiriama asmeninio efektyvumo kompetencijoms (pavyzdžiui, Cherniss, Goleman, 2001, Boyatzis, 2008). 
1 lentelè. Lietuvos valstybės tarnautojų kompetencijų modelị sudarančių kompetencijų sąrašas ir jų apibrěžtys (šaltinis: „Valstybės tarnautojų kompetencijų modelis ir jo taikymo metodika" 2014, 1 lentelè, 23-24 p.)

\begin{tabular}{|c|c|}
\hline $\begin{array}{l}\text { Eil. } \\
\text { Nr. }\end{array}$ & Kompetencija ir jos apibrèžtis \\
\hline I. & Bendrosios kompetencijos \\
\hline 1.1. & $\begin{array}{l}\text { VERTĖS VISUOMENEI KŪRIMAS } \\
\text { Supranta valstybės tarnybos paskirtị, savo veikla ir siūlymais prisideda prie } \\
\text { vertès visuomenei kūrimo }\end{array}$ \\
\hline 1.2 . & $\begin{array}{l}\text { ORGANIZUOTUMAS } \\
\text { Planuoja veiklą ir laiką, nusistato prioritetus, veikia neatidèliodamas }\end{array}$ \\
\hline 1.3 . & $\begin{array}{l}\text { PATIKIMUMAS IR ATSAKINGUMAS } \\
\text { Vykdo įsipareigojimus, prisiima atsakomybę už veiklą ir rezultatus, jų gerinima }\end{array}$ \\
\hline 1.4. & $\begin{array}{l}\text { ANALIZĖ IR PAGRINDIMAS } \\
\text { Geba atlikti situacijos analizę - išskaidyti ją ị sudètines dalis, nustatyti dalių } \\
\text { tarpusavio ryšius, išskirti esminę informaciją, parengti pagrịstus sprendimus }\end{array}$ \\
\hline 1.5 . & $\begin{array}{l}\text { KOMUNIKACIJA } \\
\text { Geba bendrauti su asmeniu ir grupèje, pasirinkdamas ịvairias bendravimo } \\
\text { priemones, užtikrindamas informacijos perteikimą bei supratimą }\end{array}$ \\
\hline II. & Vadybinės ir lyderystės kompetencijos \\
\hline 2.1. & $\begin{array}{l}\text { STRATEGINIS POŽIŪRIS } \\
\text { Tikslus suderina su valstybės prioritetais, ịvertina platesnį kontekstą, numato } \\
\text { ateities galimybes ir geba jomis pasinaudoti }\end{array}$ \\
\hline 2.2 . & $\begin{array}{l}\text { VEIKLOS VALDYMAS } \\
\text { Nustato veiklos prioritetus, organizuoja ir koordinuoja veiklą, užtikrindamas } \\
\text { tikslu igyvendinimą }\end{array}$ \\
\hline 2.3 . & $\begin{array}{l}\text { LYDERYSTE் } \\
\text { Vadovas - pavyzdys kitiems, perteikia viziją, misiją, tikslus ir ịkvepia jų } \\
\text { siekti, suteikia reikalingą emocinę paramą, ̨raukia ị sprendimų prièmimą, } \\
\text { ugdo, sukuria pozityvią darbo aplinką }\end{array}$ \\
\hline III. & Specifinès ir profesinès kompetencijos \\
\hline & Specifinès kompetencijos \\
\hline 3.1 . & $\begin{array}{l}\text { POLITINIS İŽVALGUMAS } \\
\text { Teikiamus siūlymus grindžia nacionaliniu, regioniniu ar savivaldos lygmeniu } \\
\text { aktualių poreikių analize, numato siūlymų praktinio ịgyvendinimo modelius, } \\
\text { geba užtikrinti aktualių programų, projektų ir kt. tęstinumą }\end{array}$ \\
\hline
\end{tabular}




\begin{tabular}{|c|c|}
\hline 3.2. & $\begin{array}{l}\text { INFORMACIJOS VALDYMAS } \\
\text { Geba surinkti patikimą informaciją, ją sisteminti, tvarkyti ir kaupti }\end{array}$ \\
\hline 3.3 . & $\begin{array}{l}\text { ORIENTACIJA İ KLIENTĄ } \\
\text { Su klientais bendrauja pagarbiai, išsiaiškina klientų poreikius ir suranda } \\
\text { klientų poreikius atitinkančius sprendimus, tobulina aptarnavimo kokybę }\end{array}$ \\
\hline 3.4. & $\begin{array}{l}\text { RYŠIŲ TINKLO KŪRIMAS } \\
\text { Kuria, palaiko ir plètoja ryšių tinklą, efektyviai išsprendžia problemas, } \\
\text { pasinaudodamas ryšių tinklu, siūlo ilgalaikės partnerystès strategijas }\end{array}$ \\
\hline 3.5 . & $\begin{array}{l}\text { DERYBŲ VALDYMAS } \\
\text { Geba pasirengti deryboms, valdyti derybų procesą siekdamas visoms šalims } \\
\text { naudingų susitarimų, taikyti skirtingas derybų strategijas ir taktikas }\end{array}$ \\
\hline 3.6. & $\begin{array}{l}\text { TARPKULTŪRINE் KOMUNIKACIJA } \\
\text { Supranta kultūrinius skirtumus, geba efektyviai veikti ir bendrauti skirtingoje } \\
\text { nuo ịprastos kultūrinėje ir kalbinejje aplinkoje }\end{array}$ \\
\hline 3.7. & $\begin{array}{l}\text { KONFLIKTŲ VALDYMAS } \\
\text { Geba išspręsti konfliktus: nuraminti emocijas, išsiaiškinti konflikto priežastis, } \\
\text { rasti sprendimus }\end{array}$ \\
\hline 3.8. & $\begin{array}{l}\text { KONTROLE்S IR PRIEŽIŪROS PROCESO VALDYMAS } \\
\text { Geba valdyti kontrolės ir priežiūros procesą, siekdamas užtikrinti } \\
\text { kontroliuojamų subjektų veiklos atitikimą galiojančioms teisės aktų } \\
\text { nuostatoms ir keliamiems reikalavimams }\end{array}$ \\
\hline 3.9 & $\begin{array}{l}\text { ITAKA } \\
\text { Geba padaryti įtaką kitų nuomonei ir požiūriui bei gauti jų pritarimą } \\
\text { siūlomoms idejjoms, naudodamasis teisètomis ir etiškomis priemonėmis }\end{array}$ \\
\hline$\ldots$ & Profesinès kompetencijos \\
\hline
\end{tabular}

Igyvendinant projektą parengtoje metodikoje nurodyta, kad Lietuvos valstybès tarnyboje požiūrio ị žmogiškuosius išteklius valdymo pokyčius paskatino bei argumentuotas prielaidas diegti kompetencijų modeli sudarè tam tikri veiksniai ir aplinkybès. Keletą jų reikètų išskirti:

- Narystė Europos Sąjungoje ir siekis perimti ES šalių gerąją žmogiškujų išteklių valdymo patirtį: dauguma ES šalių turi apibrèžtas valstybės tarnautojų kompetencijas ir kompetencijų modelius bei sẻkmingai juos taiko [11], [8].

- Poreikis Lietuvoje tobulinti viešojo administravimo sektoriaus žmogiškųju išteklių valdymą. $2010 \mathrm{~m}$. Lietuvoje atlikus viešojo administravimo sektoriaus atstovų apklausą nustatyta, kad pritariama Lietuvos valstybės tarnautojų kompetencijų modelio diegimui (respondentai kompetencijų modelio reikalingumą įvertino 7,35 balų iš 10 galimų), suprantama, kad kompeten- 
cijų modelio įdiegimas didžiausią įtaką turès tobulinant valstybès tarnybos žmogiškųjų išteklių administravimą (73,17 proc. respondentų visiškai ar didžiąja dalimi sutinka, kad kompetencijų modelio įdiegimas padès tobulinti valstybės tarnybos žmogiškųjų išteklių administravimą), tobulinant žmogiškųjų išteklių valdymą (63,71 proc. respondentų visiškai ar didžiąja dalimi sutinka, kad kompetencijų modelis padès tobulinti žmogiškųjų išteklių valdymą) ir padidins žmogiškųjų išteklių valdymo procedūrų aiškumą $(63,51$ proc. respondentų visiškai ar didžiąja dalimi sutinka, kad kompetencijų modelis padės didinti žmogiškųjų išteklių valdymo procedūrų aiškumą) [12]. Kompetencijų modelio diegimas valstybės tarnyboje reiškia ne tik žmogiškųjų išteklių vadybos pokytị, bet pirmiausia įstaigų kultūros pokytị, nes, apibréžiant kompetencijas, pereinama nuo orientavimosi tik ị savo funkcijų atlikimą, procedūrų vykdymą prie platesnio požiūrio ir įsisąmoninimo, kad funkcija turi kurti vertę visuomenei, įstaigai, apibrèžiama valstybės tarnautojo asmeninè atsakomybė ir indèlis (tai tampa ypač akivaizdu apibrèžus bendrąsias kompetencijas, jas siejant su valstybès tarnybos misija, vertybèmis). Be to, nustatant valstybès tarnautojo kompetencijas, aiškiai parodoma, ko iš jo tikimasi, - taip didinama ir jo asmeninè atsakomybè už tobulèjimą, skatinamas ir didesnis tiesioginio vadovo įtraukimas į žmogiškųjų išteklių valdymą (planuojant jam pavaldžių asmenų tobulëjimą, karjerą ir kt.).

- Didejja Lietuvos piliečių valstybès tarnautojams keliami kompetencijos bei žmogiškujų išteklių valdymo efektyvumo valstybès ir savivaldybių įstaigose ir institucijose reikalavimai (ir, atitinkamai, teikiamų paslaugų kokybės, veiklos efektyvumo reikalavimai). Apibendrinus 2010 m. Lietuvoje atliktos akademinès bendruomenès ir kitų ekspertų, verslo sluoksnių atstovų ir visuomenès nuomonès formuotojų apklausos rezultatus nustatyta, kad (1) Lietuvos valstybės tarnybos funkcionavimo, žmogiškųjų išteklių valdymo trūkumai yra nelanksti, sunkiai besikeičianti sistema, vadovavimo gebejjimų stygius, orientavimosi į rezultato pasiekimą, vykdomos veiklos efektyvumą trūkumas, per didelis dẻmesys žmogiškųjų išteklių administravimui, o ne realiam valdymui (kaip priežastys ịvardinti tam tikri įstatymu bazès trūkumai, atsakingų specialistų žinių ir gebejjimų šioje srityje stoka); (2) kompetencijų modelio taikymas prisidès tobulinant valstybès tarnybą (ypač žmogiškųjų išteklių valdymą), jei jis bus susietas su atitinkamais žmogiškųjų išteklių valdymo procesais (taps aiškesni atrankos, veiklos vertinimo kriterijai, kryptingesnis ugdymo ir karjeros planavimas), galimai pravers tobulinant darbo užmokesčio ir skatinimo sistemą, sukurs prielaidas valstybès tarnyboje stiprinti vadybos grandį ${ }^{8}$.

- Gerosios praktikos pavyzdžiai diegiant kompetencijų modelius Lietuvos valstybės ir savivaldybių įstaigose ir institucijose. Pavyzdžiui, Lietuvos Respublikos valstybès kontrolè kompetencijų modeli taiko nuo 2003 m., kompetencijų modelius taip pat turi parengę ir taiko Lietuvos statistikos de- 
partamentas, Nacionalinė mokejjimo agentūra prie Žemès ūkio ministerijos, Lietuvos Respublikos Seimo kanceliarija, Vyriausybės kanceliarija, Lazdijų rajono savivaldybės administracija ir kt.). Valstybès tarnybos departamento iniciatyva $2012 \mathrm{~m}$. lapkričio mèn. - $2013 \mathrm{~m}$. sausio mèn. atlikus ịstaigų apklausą (pradinę informaciją surenkant raštu, o tikslinamuosius pokalbius vykdant telefonu ir susitikus tiesiogiai) nustatyta, kad iš 543 ịstaigų sąrašo 6 įstaigos turi pasirengusios kompetencijų modelius ir juos taiko žmogiškųjų išteklių vadyboje (dažniausiai kompetencijų vertinimą atlieka mokymo planavimo (kompetencijos tobulinimo) tikslais, kai kurios taiko kompetencijų vertinimą atrankoje, tik viena - planuoja sieti su motyvavimo sistema), dar 8 turi neseniai pasirengusios kompetencijų modelius ir atlikusios bandomuosius taikymus, 1 - apklausos metu rengè ir planavo diegti.

\section{Kompetencijų modelio taikymo perspektyvos įvairiose Lietuvos valstybès tarnybos žmogiškųjų išteklių vadybos srityse}

Daugelis autorių [2], [3], [4] mano, kad žmogiškųjų išteklių vadyba šiuo metu patiria labai rimtus pokyčius ir tikslesnių kompetencijų modelių, patikimesnių kompetencijų vertinimo metodikų dèka sukuria žymiai geresnes perspektyvas pasiekti kokybiškai naujų rezultatų vystant patị svarbiausią kiekvienos organizacijos išteklių - jos žmones. Sparti pažanga šioje srityje jau leidžia mums kalbèti apie kompetencijomis grịstą žmogiškųjų išteklių vadybą [3 , p. 55].

Darbuotojų kompetencijos palaipsniui tampa žmogiškųjų išteklių vadybos šerdimi, kuri tiesiogiai siejasi su beveik kiekviena jos atliekama funkcija. Visų pirma tai žmogiškųjų išteklių planavimas, kai susitelkiama ị kokybinius rodiklius, tokius kaip darbuotojų talentai ir tai, kokią naudą jie galès atnešti savo organizacijai. Kita svarbi funkcija - tai darbuotojų paieška ir atranka. Kompetencijų modelis gali būti sẻkmingai panaudojamas vykdant centralizuotą atranką ị valstybès tarnybą, kurios metu gali būti ịvertintos bendrosios visiems vadybinès ir lyderystès kompetencijos, tiriami bendrieji mąstymo gebejjimai. Tolesniame etape, organizuojant konkursus konkrečiose įstaigose, remiantis kompetencijų modelyje suformuluotais kriterijais, ìvertinamos specifinès ir profesinès darbuotojo kompetencijos. Sprendimai vykdant darbuotojų atranką priimami remiantis asmens pasiektais rezultatais ar tinkamai veiklai vykdyti turimu gebèjimu ir lyginami su tai pareigybei sukurtu kompetenciju modeliu.

Darbuotojų veiklos vertinimas taip pat atliekamas pagal iš anksto sukurtą pareigybės kompetencijų modelị. Asmeninių darbuotojų kompetencijų ir keliamų reikalavimų neatitikimas šalinamas organizuojant tikslinius ir kryptingus mokymus ir rengiant individualias darbuotojų ugdymo programas. Kompetencijų modelis drauge su darbuotojo veiklos vertinimo rezultatais tampa pagrindu objektyviam mokymo ir ugdymo poreikių nustatymui. Be to, veiklos vertinimo rezultatai leidžia stebèti, kaip darbuotojas tobulëja ir jo asmeninès kompetencijos atitinka kompetencijų modelio apibrèžtus reikalavimus. 
Lietuvos valstybės tarnybai sukurto kompetencijų modelio nerekomenduojama sieti su valstybės tarnautojų darbo užmokesčio ir skatinimo sistema (darbo užmokestį ir skatinimą sieti su valstybės tarnautojo kategorija ir / ar pareigybių grupe (Olandijos valstybės tarnybos pavyzdys ${ }^{3}$ ) ir / ar veiklos rezultatais (veiklos rezultatų ir skatinimo susiejimo praktika dažniausiai taikoma verslo sektoriuje). Norint susieti kompetencijas su darbo užmokesčio ir skatinimo sistema, turi būti sudarytos kompetencijų objektyvaus įvertinimo galimybės (Belgijos pavyzdys, kai valstybès tarnautojas, dalyvavęs atitinkamoje mokymų programoje ir išlaikęs testą, patvirtinantị aukštesnès kompetencijos lygio igijimą, gauna „kompetencijos išmokas"). Norint pradèti taikyti tokią kompetencijų vertinimo sistemą, būtina sukurti išplèstinę patikimų ir validžių kompetencijų ịvertinimo testų bazę, parengti atitinkamas mokymo programas, sukurti infrastruktūrą (pavyzdžiui, kurti kompetencijų vertinimo centrus, parengti vertintojus), - visa tai reikalauja didelių finansinių, laiko ir žmogiškujų investicijų ir todèl šios galimybès taikymas svarstytinas vèliau, pirmiausia kompetencijų modelị įdiegus kituose ŽI valdymo procesuose - atrankoje, vertinime, planuojant mokymą ir ugdymą bei karjerą, išsamiai ịvertinus sąnaudų ir vertès santykị [14].

\section{Išvados}

1. Kompetencijomis grịsta žmogiškųjų išteklių vadyba atsispindi svarbiausiuose strateginiuose valstybės dokumentuose. Lietuvoje egzistuoja bendras supratimas ir politinis konsensusas dèl kompetencijų modelio diegimo būtinumo. Net ir keičiantis valdančioms politinèms jègoms, ši nuostata išlaiko savo tęstinumą.

2. Valstybės tarnybos departamentas inicijavo kompetencijų modelio sukūrimą visos Lietuvos valstybès tarnybos mastu, taip tapdamas pagrindiniu pokyčiu žmogiškųjų išteklių vadyboje diegimo koordinatoriumi.

3. Šiuo metu egzistuojantis teisinis reglamentavimas Lietuvoje dar neatspindi naujausių žmogiškųjų išteklių vadybos transformacijų ir neįtvirtina kompetencijų modelių taikymo.

4. Kadangi darbuotojų kompetencijų modeliai yra stabilesni ir lęčiau kinta negu darbo pareiginiai aprašai, jie gali ir privalo užimti centrinę vietą Lietuvos valstybės tarnybos žmogiškujjų išteklių vadyboje. Kompetencijų modeliai gali būti naudojami darbuotojų paieškai ir atrankai, veiklos vertinimui, ugdymui, mokymų poreikiui ir mokymų efektyvumui nustatyti, kompensavimo už darbą sistemoms kurti.

3 Remiantis tyrimo „Užsienio šalyse taikomų kompetencijų modelių bei pareigybių sisteminimo principų tyrimo ataskaita“ (ES ir Lietuvos Respublikos valstybės biudžeto lèšomis finansuojamo ir VTD ịgyvendinamo projekto „Valstybès tarnyboje būtinų kompetencijų analizė ir valstybės tarnautojų pareigybių aprašymų katalogas“ veiklos „Užsienio šalyse taikomų kompetencijų modelių bei pareigybių sisteminimo principų tyrimas“ rezultatais, 2011). 


\section{Literatūra}

1. Bissessar, A. M. Challenges of Competency Testing in a Divided Society. Public Personnel Management.Summer. 2010, Vol. 39, No. 2, 97-115.

2. Boyatzis, R. E. The Competent Manager: a model for effective performance. New York: Wiley, 1982.

3. Bratton, J., Gold, J. Human Resource Management. Theory and Practise. PALGRAVE MACMILLAN, 2007, 66.

4. Dubois David, D. Competency-based human resource management, Palo Alto (California): Davies-Black Publishing, 2004.

5. Gangani, N., McLean, G. N., Braden, A. R. A Competency-Based Human Resource Development strategy. Performance Improvement Quarterly. 2006, Vol. 19, No. 1, 127-139.

6. Horton, S., Hondeghem, A., Farnham, D. Competency Management in the Public Sector. International Institute of Administrative Science, 2002.

7. McClelland, D. C. Testing for Competence Rather than for Intelligence. American Psychologist. 1973, 28, 1-14.

8. Spencer, L. M., Spencer, S. M. Competence at Work: Models for Superior Performance. New York: John Wiley \& Sons, Inc., 1993.

9. Op de Beeck, S. \& Hondeghem, A. Managing Competencies in Government: State of the Art

10. Practices and Issues at Stake for the Future [vertrouwelijk rapport]. 2010, 125 p.

11. Užsienio šalyse taikomų kompetencijų modelių bei pareigybių sisteminimo principų tyrimo ataskaita (ES ir Lietuvos Respublikos valstybės biudžeto lèšomis finansuojamo ir VTD igyvendinamo projekto „Valstybès tarnyboje būtinų kompetencijų analizè ir valstybės tarnautojų pareigybių aprašymų katalogas“veiklos „Užsienio šalyse taikomų kompetencijų modelių bei pareigybių sisteminimo principų tyrimas“ rezultatas, 2011).

12. Valstybès tarnautojų kompetencijų modelio bei pareigybių aprašymų katalogo poreikio bei taikymo galimybių analizè. Lietuvos viešojo administravimo sektoriaus bei privataus sektoriaus apklausos apibendrinti rezultatai (ES ir Lietuvos Respublikos valstybės biudžeto lèšomis finansuojamo ir VTD ịgyvendinamo projekto „Valstybės tarnyboje būtinų kompetencijų analizè ir valstybės tarnautojų pareigybių aprašymų katalogas" rezultatas, 2010).

13. Valstybės tarnautojų kompetencijų modelis ir jo taikymo metodika. 2014, 20 p.

14. Valstybès tarnautojų kompetencijų modelis ir jo taikymo metodika. 2014, 17 p.

Reda Rekašienè, Tadas Sudnickas,

\section{Competency Models Development and Application Prospects in Lithuanian Civil Service}

\section{Summary}

The paper provides an overview of Lithuanian State Department activities in implementing competency models in Lithuanian public service. Based on the national strategic documents the project was initiated to implement competency models. The paper 
presents the factors and circumstances of the competency model implementation, as well as reasoned assumptions of creating such a model. The perspective of various possibilities of the competency model application in different human resources management areas is presented. A gradual transition from the traditional to the competency -based human resource management in Lithuania's civil service is discussed.

Reda Rekašienè - Valstybès tarnybos departamento Žmogiškujų išteklių plètros skyriaus vedèja.

E. paštas: reda.rekasiene@vrm.1t

Tadas Sudnickas - Mykolo Romerio universiteto Politikos ir vadybos fakulteto Vadybos instituto direktorius.

E. paštas: tsudnick@mruni.eu

Reda Rekašienè - Head of Human Resource Development Division, Civil Service Department E-mail: reda.rekasiene@vrm.1t

Tadas Sudnickas - Director of the Institute of Management, Faculty of Politics and Management, Mykolas Romeris University.

E-mail: tsudnick@mruni.eu

Itteiktas 2014 m. rugsėjo 10 d.; recenzuotas; parengtas spausdinti lapkričio mèn. 